\title{
ART AND CIVIL SOCIETY: FROM PROTEST TO COOPERATION
}

\author{
Katarzyna Niziołek \\ University of Białystok, Institute of Sociology, \\ Plac Uniwersytecki 1, 15-420 Białystok, Poland \\ E-mail: katarzyna.niziolek@gmail.com
}

\begin{abstract}
In the article, adopting the democratic transformation perspective, the author focuses on art as a specific area of civil society. With an eye on Poland, various forms of artistic activism are analyzed and compared, from artistic vanguard and protest art of the communist period, to the practices of cultural democracy and social art of the present day. In particular, the concept of social art is explained and exemplified with three model projects, each set in a different context - of an open public space, local community and minority group, and each representing a different set of social functions.
\end{abstract}

Keywords: cultural democracy, cultural organizations, participatory photography, protest art, social art.

doi:10.3846/limes.2010.15

"To the time, its art, To the art, its freedom".

From the facade of the Secession Palace, Vienna, Austria.

\section{Introduction}

Adopting the democratic transformation perspective, in my paper I focus on art as a specific area of civil society. Earlier Polish studies, that made a link between aesthetics and citizenship were mostly rooted in the reality of the 1970s and 1980s, and inevitably reduced this kind of engagement either to political opposition, or counterculture. In contrast, in nowadays democratic Poland, we may observe a much wider variety of bottom-up activities - of non-governmental organizations, local communities, social movements (including global) or informal groups of citizens - in which art is used as an instrument to further some common aim, or pursue some common good (still defined in terms of social change). While protest remains an important dimension of such activities, like in the case of Polish alter-globalists, feminists, or the present-day Orange Alternative (who have continued to operate after the communist regime collapsed in Poland), a number of other crucial civic functions are emerging: articulation, creation of social bonds, or mobilization, to mention but a few.

\section{Artistic vanguard and protest art under communism}

According to Marian Golka (1996), a Polish sociologist of art, one of the major functions of art in general is ideological, including critical artistic expression. Art serves 
its ideological function when it is used to impose certain values on the public or, conversely, to question the dominant axiology. In totalitarian regimes, however, the latter is impossible, and art tends to be completely subjected to the state doctrine. Due to its autonomous potential art is perceived by totalitarian authorities as a corrupted and dangerous medium. In one of the Polish Film Chronicles from the Stalinist period artistic vanguard, as represented by paintings of Pablo Picasso and Salvador Dali, was described in the following words (Nowa sztuka 1950):

"Its pessimism is intended to break the resistance of the candidates for cannon fodder. To take away their faith in humanity, crush their desire for rebellion, their will to fight for a better tomorrow. In the future murderers of women and children these pictures are to wake disgust for people and their matters, teach not to think, unleash the lowest instincts".

Both the Nazis and Communists fought with the artistic vanguard almost as fiercely as with the political opposition. Official bans on artistic activity, repressions towards the creators, displacement of modern art from public life (so called, museum purges) and its replacement with artistic propaganda literally turned a number of modern works of art into ash, often in accompany of applauding crowds.

Yet in Poland, unlike in other communist countries, by the end of the 1950s the modern vanguard had been already released from the party control. The turning point was the Second Exhibition of Modern Art in Warsaw's Zachęta in 1957. The permission to create vanguard works in visual arts became official in 1958/1959 due to the Polish exposition at the International Art Exhibition of the Socialist Countries in Moscow. The exposition, which included "contemporary trends", as exemplified by colorist paintings of Adam Marczyński, was severely criticized by the other delegates and hosts for its aberration of socialist realism, and turn towards abstractionism, formalism and Occidentalism. Still, the acceptance of modern vanguard by the Polish authorities had its hidden political aim. This was how they accentuated their - however limited to cultural politics - independence from the Soviet Union, and tried to create a more liberal image within their own grassroots, presenting themselves as open, progressive and tolerant. Due to the program focus of modern art on the autonomy of the artist and his work, which was seen in the free choice of the formal means of expression, such art was perceived as apolitical and, from the perspective of the authorities, unthreatening (Kucharska 2004; Piotrowski 2004). In other words, the Polish communist authorities decided not to bother their artists, as long as their artistic freedom did not interfere with politics. If Polish artists met with repressions, it was not connected to their art, but their political views and independent public activity. And many an artist did consider this situation as artistic freedom. But such artistic freedom did not equal freedom of expression. It was politically empty. Putting both socialist realism, and "pacified" modern vanguard aside, there was no room and no desire for any kind of artistic citizenship at the time in Poland. Only later did art become the domain of counterculture and political opposition. But it was not until 1970.

In consequence, the Polish "art world" of the time was completely uninterested in social problems, or political issues. Ryszard K. Przybylski (1993) notices that some 
artistic trends, such as social reportage, or chronicle of everyday life, which had grown from the contestation of the 1960s, and gained popularity in the West, were almost absent in Poland. This withdrawal from political and social engagement was true not only for the visual arts, but also for the other areas of artistic creation. For instance, in her book on the student theatres of the 1970s Aldona Jawłowska claims that though from the mid 1950s to the end of the 1960s those theatres had undergone a major transformation from political agitation (when they were totally surrendered to non-artistic, regime-defined aims), to artistic experiments typical of the world theatrical vanguard, they showed no interest in the surrounding reality. It was only around 1970 when the student theatres became "engaged”, and started referring to the social and political reality by using theatrical means to judge it on the basis of their own experiences (Jawłowska 1988).

The Polish paradox was that the relative freedom of artistic expression in the formal (aesthetic) sphere prevented the development of critical attitudes in the socio-political sphere, and brought the side-effect of social and political disengagement of the arts. At the same time, direct repressions towards artists in Czechoslovakia, Hungary, or Eastern Germany (DDR), made their artistic expression a political protest per se. Even the members of the Fluxus movement, although they had no declared connections to politics, faced incarceration there. According to Maria A. Potocka (2008), Fluxus got so influential because they made use of humor, doubt and abstraction. Perhaps that was why they were so annoying to the communist authorities in Eastern Europe. After all, their artistic strategy was a complete contradiction of the communist, centralized, and bureaucratically organized order. It is enough to mention the chance events, one of the key components of Fluxus activities. But above all, it must have been the sole idea of freedom and creativity that distressed the authorities most. The Fluxus were creatively free: "promoted imagination, change, movement, growth - FLUX in art" (George Maciunas in Smith 1998: 234). And even more importantly, they put human creation before the work of art, demonstrating "that anything can substitute for art, and anyone can do it" (George Maciunas in Smith 1998: 231). Writing on the history of Fluxus, Owen F. Smith (1998) concludes that they were more like a generalized attitude or life philosophy than an organized group.

In Poland, apart from few exceptions, and somehow despite the adoption of critical means, such as happening or conceptual art, till the 1970s there was no wider criticism of the authorities expressed in art, and no connections between art and citizenship. In the 1970s and 1980s, aesthetic sensitivity, which Maria Ossowska (1992) considered one of the essential characteristics of a citizen figure, finally fueled contesting and oppositional attitudes, and made its way to the public. However poorly described by social sciences, art of the time must have had a huge impact on the cultural and social consciousness of its contemporaries and successors. It is enough to mention the student theatres, which created community around alternative values and lifestyles (Jawłowska 1988), protest happenings of the Orange Alternative (Marchlewski 1991; Pęczak 1991; Misztal 1992), or para-artistic interventions and workshops of some environmentalist circles (Gliński 1996). The common trait of all those activities was 
their opposition towards the state that on one hand, suppressed open grassroots articulation, on the other, limited critical artistic expression. No more were those activities merely artistic projects. They transformed artists and their public into protesting and contesting citizens. Yet, like the Orange Alternative, they had never formed an organized opposition, or become any explicitly political force. Instead they offered a cultural alternative to the dominating order of meanings, be it communist, religious, or materialist-industrialist. In a way, they ran ahead of their time, as the question of meaning production is a universal one, i.e., valid both under socialist, and post-socialist conditions (compare to Misztal 1992).

With the oppressive state artist-citizens could not cooperate. It is obvious that under totalitarian or authoritarian conditions a number of regular grassroots practices cannot be employed. It is the lack of political opportunities, such as freedom of assembly, or the right to protest, and also the costs of open public articulation which take the form of repression, that prevents potential activists from explicit political action. Still, resorting to art as a means of collective action seems to be one of the few tactics bringing desirable effects in undemocratic regimes as well. Artistic action is not explicitly political, may hide the political message under layers of abstractions, and cannot be easily reduced to political claims. In respect to social change, it remains, as if, discreet. When it does bring change, it needs not to happen under a large and screaming banner "rebellion". On the contrary, it may set up transformations under the auspices of a mocked approval of the oppressive regime, like it was typical of the Orange Alternative and its happenings (e.g., Warsaw Pact - the Vanguard of World Peace, The Eve of the Great October Revolution, The Day of the Secret Agent). A participant describes such an event: "We were walking down the street and shouting Militia is likeable, and you could see helplessness of those dumb ZOMO officers, who had completely no clue what to do with the people approaching them, and queuing to show their IDs" (Zmarz-Koczanowicz 2002) $)^{1}$. This ambiguity of meaning was reflected in the reactions of the authorities to the Orange happenings, which ranged "from neglecting it as an opposition force back in the 1983-1984, through criticizing it for its alleged youthfulness or immaturity in 1986-1987, ridiculing it as fools' play in early 1988, and to persecution and beating up of its members late in 1988” (Misztal 1992: 57).

What the authorities perceived as problematic was the very source of the Orange Alternative influence, that is, its indefinable quality, spontaneity, and lack of clear political affiliations. Their activist strategy was simply to turn the everyday street life into a protest event, in which everyone, including the militiamen was to participate: "You called upon people to go and honor Vladimir Ilyich, and the ZOMO officers stood and yelled - I will show you the fuckin' Lenin" (Zmarz-Koczanowicz 2002). The Orange ridiculed various aspects of socialist reality, and highlighted its

\footnotetext{
${ }^{1}$ The citation comes from the documentary "Generation 89" (2002) by Maria Zmarz-Koczanowicz. This and the following citations from the film have been translated into English by the Authoress. So have been all the other citations from Polish literature or websites.
} 
paradoxes, but also invited people to spontaneous, public participation - something that had been largely forgotten under the authoritarian, bureaucratic and policized regime. "It's major accomplishment [...] - writes Bronisław Misztal (1992: 65) - is that it has dispelled the myth of political order, thus doing away with fear, and has normalized the street protest”. Its social and historical importance comes from the fact that it was the only new social movement in the Polish streets in the $1980 \mathrm{~s}^{2}$, which resorted to non-political, cultural and artistic repertoire, instead of associating with the organized opposition, and negotiating with the ruling elite within the political system: "I reckoned it was a much more powerful weapon against communism - such a laugh, and contempt. That was it - there were loads of contempt in it, while in politics, there were compromises and negotiations" (Zmarz-Koczanowicz 2002).

In this light, art presents itself as a "universal" tactic of collective action, capable of launching citizen participation under any political or systemic circumstances, which can be (and is) resorted to by organizations and movements both in totalitarian, and democratic countries. Art can also be used as a medium of communication between the two, like in the case of arpilleras $^{3}$ made by Chilean shantytown women under Augusto Pinochet's dictatorship, and distributed through international advocacy networks in order to mobilize resources and support for their cause (Adams 2002; Agosín 2008).

\section{Towards cultural democracy and social art}

In the democratic state and society art becomes a meaningful citizen practice that goes far beyond protest and maintenance of international focus. Under new conditions, it gains new possibilities of articulation and mobilization both on the local, and global level. In the latter case, it is undoubtedly not only due to the political shifts of the early 1990s, but also the increase in the worldwide diffusion of collective action. However, democracy challenges art as a collective citizen action, too. It raises new expectations, such as the development of public sphere, engagement of local communities,

\footnotetext{
${ }^{2}$ Although many a sociologist would doubt whether the Orange Alternative of the 1980s was a social movement at all, and a new social movement in particular, a number of characteristics can be observed that the Orange shared with their counterparts in the West, like: 1) targeting pervasive rationalization, social control, and conformity to the system (be it socialist, or capitalist; totalitarian, or democratic); 2) attracting a wide range of participants (from various social backgrounds and walks of life); 3) organizing in an informal and spontaneous manner, resorting to direct action, and relying solely on the unconventional repertoire of contention.

${ }^{3}$ Arpilleras are patchwork pieces telling stories of poverty, state repression, and violations of human rights under oppressive regimes. They were primarily introduced by Chilean women under Augusto Pinochet's regime. The practice of making arpilleras and distributing them abroad began out of economic necessity. But since they were made by mothers, wives, and daughters of the regime victims (the disappeared), who in this way expressed their grief and resistance, arpilleras became a major tool for organizing international campaign against the Pinochet's dictatorship: raising money and interest in the quest for justice and democracy in Chile. Today Chilean arpilleristas continue their work to pass on their stories to others in order to maintain their memories. Their movement has also inspired similar activism elsewhere; arpilleras have since been created around the world, from Peru, to Afghanistan, to South Africa.
} 
and empowerment of minority groups. It also requires some level of cooperation with the government ${ }^{4}$, not such easy a task after decades of opposition and resistance. With a number of factors different, including the structure of political opportunities, and available repertoire (tactics and means) of artistic activism, art is becoming even a more powerful instrument of citizen practice.

On the other hand, art (or at least some areas of art) is heading towards democratization itself. What begun in the West as the people's or community art movement in the 1970s, came to Poland twenty years later. The various attempts of cultural democracy $^{5}$, philosophically rooted in the idea of common participation, have changed the vision of what art is for and who may create it, introduced new, not necessarily institutionalized or professionalized, actors to the area, and finally, redefined the functions of art in society. It has become an enclave of civil engagement, and one of a radiating quality (Niziołek 2009b). At present, not only is art seen as conceptually or thematically connected to the wider society (i.e., not restricted to the "art world"), but also, and even more importantly, as participatory and functional, and as such, it is evolving into a tool of social change in the hands of the more or less organized citizens.

In particular, the non-profit, non-governmental organizations (NGOs) are emerging as increasingly important actors in the area of art (and culture in general) in Poland. Altogether, there are currently circa nine thousand registered and active cultural organizations (Gumkowska 2009). As the latest study of the third sector in Poland reveals, almost $13 \%$ of the national NGOs declare "culture and art" as the main field of their activity, and further $11 \%$ - as one of their activity fields. This means that nearly $1 / 4$ of the Polish third sector is constituted by organizations somehow involved in cultural or artistic endeavors (Gumkowska, Herbst 2006). Among these organizations: 31.7\% point to publishing, libraries and media as the specific areas of their focus; $32 \%$ are engaged in theatre, music or film-making; 30.5\% deal with cultural heritage and its protection; and $25 \%$ operate in the sphere of fine arts, photography and architecture (Gumkowska 2009). Another survey shows that in 2007, 13\% of Poles experienced some form of contact with a cultural organization, that is, heard of it, took part in its activities, or used its services (Baczko, Ogrocka 2008). Still, as Poles in general tend to confuse non-governmental organizations with public institutions, larger (though not specific) numbers may be inferred. On the other hand, cultural organizations tend to cooperate with public institutions, such as schools, community centers or museums, more often than other non-profits, and frequently see local governments as their strategic partners. The reason behind the latter is largely mercantile, as local governments

\footnotetext{
${ }^{4}$ Cooperation includes common aims - defined in terms of public good or benefit, favorable legal conditions facilitating bottom-up initiatives, as well as financial support for social organizations.

${ }^{5}$ Cultural democracy is a philosophical and political idea that stems from the vision of art institutions as unrepresentative (which do not operate in the interests of a wider society) and of their potential transformation towards more equal representation. The latter is to be achieved by means of wider participation. In a cultural democracy people who normally do not participate in art not only gain access to art institutions (such as museums or galleries), but also take part in the process of defining and creating art. Hence, cultural democracy opposes artistic elitarism and cultural exclusion, that is, the practice of keeping the majority of people out of the "art world" and rejecting their right to cultural creativity (e.g. Webster 1997).
} 
strongly support cultural organizations financially. Over half (52.3\%) of these organizations make use of local public funds, and the support they get adds up to $18.8 \%$ of their incomes. This makes local governments their most important sponsors. However, when one compares the amounts granted to cultural NGOs, other NGOs, and cultural public institutions, we find out that only $3.7 \%$ of what local governments give to the third sector supports cultural activity, and only $2.1 \%$ of their total spending on culture gets to NGOs (Gumkowska 2009). These findings put some light on the quality of cooperation between the public sector and cultural organizations.

Back to the notion of cultural democracy, it is important to realize that not all the organizations that declare "culture and art" as the field of their activity are dedicated to the idea of creative participation to the same extent. Neither are they all equally committed to the ends of public benefit. Some simply focus on professional cultural or artistic creation. Other just promote culture and art (bring it to wider audiences): organize festivals, run galleries (especially, so called, non-profit galleries), and such. Another group of organizations deal with cultural education and animation. There is also a number of amateur or hobbyist associations, such as choirs, orchestras, dance groups, or theatres. In 2008, among Poles who declared social, voluntary engagement, around $1 \%$ were involved in such associations ${ }^{6}$ (Wciórka 2008). And finally, there are organizations, which use art in a very specific manner, that is, as a means, medium, tool, method or resource (not an aim in itself), to achieve some social (public) goal, such as: civic education, social mobilization, re-socialization, preventing marginalization, or revitalization of urban spaces, to mention but a few.

It seems theoretically justified to define the latter as "social art". On one hand, the adjective "social" suggests a parallel to social activity and social organizations (as social art takes place in the same sector of society); on the other, it highlights the distinction of social art from public art, community art, activist art, and other similar phenomena, with which it should not be confused ${ }^{7}$. I propose to look at social art as a combination of five crucial elements ${ }^{8}$ :

1. The aim or result of an activity (social change or public benefit);

2. The addressees of the activity (broad social groups or categories);

3. The way the addressees are engaged in the activity (no barriers of participation or reception);

4. The place where the activity is carried out (public, ininstitutional sphere);

5. The bottom-up quality of the activity (spontaneity, self-organization, responsiveness, etc.).

Social art may be created by individuals, groups or communities (of different kind, and varied closeness of inner bonds), who act in the mezzo-sphere (between the

\footnotetext{
${ }^{6}$ At the same time, around $5 \%$ are involved in the activity of educational organizations, which makes the largest group of volunteers.

${ }^{7}$ For analysis of the distinction between social art and public art, community art, and activist art (see Niziołek 2009a).

${ }^{8}$ The concept of social art has been first introduced by the Authoress at the 13th Polish Congress of Sociology in 2007 (see Niziołek 2008).
} 
micro-private and macro-public), beyond "traditional" political institutions (Offe 1995). It is usually set in the context of an open public space, local community, or minority group (i.e., a group of a lower social status and limited possibilities of citizen or political action). In these contexts, it takes a number of varied and often innovative forms - of an artistic installation, street graffiti, mural, poster, billboard, theatre, happening, participatory photography, mental map, stilt training, etc. Dependant on the context and form, it may fulfil at least ten distinct citizen functions: articulation of social problems and needs, unmasking symbolic messages, space revalorization, communication with participants or addressees of an action, mobilization of participants, creating social bonds, identity construction, social protest, resource mobilization, and changing attitudes.

To illustrate the concept of social art, the following sections of the article present and scrutinize three model projects: 1) Oxygenator, an outdoor installation by a contemporary artist, Joanna Rajkowska; 2) Bridge over the Ocean, a Polish-Indian cooperation involving youngsters from Nowa Wola in Podlaski region, Poland, and young Oneidas from Ontario, Canada; and 3) Our World in 36 Snapshots, a local initiative aimed at integration of Polish and Chechen children in a Bialystok primary school.

\section{Oxygenator}

The Oxygenator was installed in Warsaw in 2006. Rajkowska, the authoress, has defined her work in terms of a public project, in which the issues of placement and place transformation played the most important part ${ }^{9}$. Within the project framework, a small pond was built in the middle of a triangular lawn at Grzybowski Square. The pond was decorated with water lilies and other plants, and equipped with ozone- and mistmakers, which served to fill the air with oxygen, and keep it around in the form of hanging mist. Around the pond, the artist placed futuristic benches, on which people could sit, and breathe with the oxygen-rich air. The primary addressees of the project were the city dwellers and visitors: "a strange melange of outcasts, employees in the close-by office buildings, plumbers buying taps and basins, suspicious elderly ladies from the nearby blocks of flats, walking their dogs out, and tourist groups from Israel, surrounded by bodyguards, and isolated from everyone else"10. The project exposed dehumanization of public places, such as Grzybowski Square, where no human needs seem to have been considered by planners. It released spontaneous reactions towards a positive change in the surrounding, and hence, brought out the people's needs. For these reasons, city decision-makers and planners may be considered to be the secondary addressees of the project.

As a public project, Oxygenator first and foremost belongs to the category of art as public spaces (Kwon 2002). The concept comes from the principle that art should be appropriated to the place in which it is to be located. This strategy is based on "estab-

\footnotetext{
${ }^{9}$ See $<$ http://www.rajkowska.com/pl/oxygenator.php $>$.

10 Ibidem.
} 
lishing a direct formal link between the material configuration of the art work and the existing physical conditions of the site - instead of emphasizing their disconnection or autonomy [...]. Such an approach was advocated as an important step toward making art works more accessible and socially responsible, that is more public" (Kwon 2002: 66). The idea of an integrative relation between the art and site is usually materialized in the possibility of physical participation of the recipient in the art work. In other words, art as public spaces is an art that serves some utilitarian function in the space: gives shadow, allows to sit and to rest, or offers some kind of relaxation. This is how it initiates physical interaction with the recipient. It is exactly the specific way of participation in the art work that decides on its public character. Art becomes accessible, because instead of incomprehensible symbolic codes, it offers a rewarding experience of space and its usage. Apart from reaching larger audiences, the artist becomes capable of co-designing, together with architects and planners, the city spaces. Rajkowska's Oxygenator provides a good example of this approach.

However, the Oxygenator demonstrates one more effect, which refers rather to its social than architectural functions, and takes it beyond the category of art as public spaces, as described above. This is the creation of social spaces, not so much facilitating the interaction with art, as with other people present in these spaces. Not only did the Oxygenator create an airy enclave in the middle of a congested big city, inviting to rest and relax. It also created a place for meeting and sharing. Filling empty city plazas with benches, lamps, trees, ponds, sculptures, and so on, projects like this often create places for being together, which the contemporary commercialized urban spaces are scarce with. Their public character is, hence, connected to the function of socializing the recipients. They bring people together in physically and symbolically transformed spaces, which due to this transformation begin to function as more or less permanent, contemporary agorae. "Instead of creating artefacts, an artist, using Beuys's concept, creates social sculptures, i.e., new forms of people's gatherings, while art is freeing its public potential" (Szreder 2008: 42).

One may still ask why include the Oxygenator in the category of social art, and not simply public art. The answer lies right in its combined characteristics as described above. Although operating in public, often ininstitutional sphere, is the characteristic that social art shares with public art, it cannot be reduced to it. Rajkowska seems to place social impact of her work before its artistic value, or in other words, treat art as a means of social change. Like Joseph Beuys once put it, unless art changes society, it is no art at all. She gives her art away to the people. It works like a "trigger", but it is not a finished "object of art" before people react to it. She describes this phenomenon in the following words:

\footnotetext{
"It seems to me that what is most important is to initiate the relation and give power to the people. Each person has in their head this whole unfathomable apparatus, and you never know what they may think, what intellectual tools they would use. Like in a mirror, they see themselves reflected in a given situation. They see as much as they want, and there is no point in expecting more. People deeply feel whether something belongs to them, or not. They feel it right away, whether they can do something, or not. When they can't, they go home to watch TV. But when they can, it turns on an
} 
infinite range of possibilities for them. It is enough to give something to them. To create a space, a place, a situation. And leave it"11.

When she built her Oxygenator, she created a place where people could sit and exhale. She contrasted a nobody's urban lawn that the place was before with a lively gathering point for people of different sexes, ages and trades that the place became after her intervention. Moreover, she obviously responded with her project to basic human needs, and hence, could bring people together to a place where they were able to satisfy them. The Oxygeneretor was such a huge success for the authoress not because she opened her art to the public, but because she managed to provide for human needs, for one thing, pointing to the dehumanization of urban spaces, for another - to peoples' longings for a better place to spend their time and socialize at. She did not create something to be considered beautiful, but something needed. And it was obviously not the oxygen that people needed, but a reason and place to gather together.

"I try to build some delicate social relations on a very basic level - says Rajkowska. Such as, in the case of the Oxygenator, a momentary neighbourhood, a public space open to collectiveness, be it as simple as realizing that we breathe with the same air, that we are together here and now. [...] Although those situations are so transient, I believe each movement that makes people gravitate towards each other on a completely new basis must be good. Perhaps the relations that emerge aside the official public sphere are more effective" 12 .

The other two projects also bore a trait of public art. Both resorted to participatory photography ${ }^{13}$, and the photographs were later presented to a wider auditory. However, they were neither inspired, nor carried out by a professional or institutionalized artist, like Rajkowska.

\section{Bridge over the Ocean}

Bridge over the Ocean was a Polish-Indian cooperation involving youngsters from Nowa Wola in Podlaski region, Poland, and young Oneidas from Ontario, Canada. On one hand, the project was aimed at building social bonds within the local community, strengthening local identity, and providing the local people with a sense of value and exceptionality. On the other hand, it was designed to bridge cultural differences, and facilitate the development of intercultural competence among the participants. It was addressed to children and teenagers, as well as the whole local community, and the partner community in Canada. The young participants were engaged in the project

\footnotetext{
11 Ibidem.

12 Ibidem.

${ }^{13}$ Participatory photography is a technique used both in social (civic) activity, and social research, in which the participants of the activity/research take photographs of those elements of their experience and surrounding that they select themselves as relevant and meaningful. The instruction is usually very simple, for example, to photograph their own world, their working environment, or - with disadvantaged groups - what "oppression" means to them.
} 
mostly as photographers and story-gatherers. They were supported by the older members of the community, parents and grandparents, who played the important role of informers. On this level the project bridged not only the intercultural, but also intergenerational distance. However, it was the children and their unspoilt insight into the reality of Nowa Wola that constituted the core of the project activities and results:

"The youngest asked questions that frequently seem to pass unnoticed to the mature minds. They were keen on the sensual details such as smells in their great grandparents' houses [...], or how the sweets their grandparents had in their childhood tasted. Though seemingly trivial, the questions revealed a particular inquisitiveness of the young mind, uncorrupted by the obvious" (Fron 2008: 180).

Projects such as Bridge over the Ocean are rooted in the local community context, as defined by the relation to the place (locality), quality of social bonds and common identity. Such art can physically change the space of living (like community murals do), or change the habits and attitudes of the engaged people. It may teach regard for the place, strengthen the sense of responsibility for it, or convey a powerful and positive massage that the place is something valuable, or even unique. The latter is highlighted by Bartosz Hlebowicz, one of the project's coordinators:

"Today we know that Nowa Wola is a unique point, as are its young inhabitants. And this is not because of an apparently interesting mixture of Polish, Ukrainian and Belarusian influences on the "native" culture, but because of something more fundamental: the way the young people perceive the world and the kind of dreams they have" (Hlebowicz 2008: 8).

In the light of the transformative and urban-environmental education theories, the space and its exploration are an important aspect of the individual and social development of children and youths. Firstly, space discovery makes a source of knowledge for the young; secondly, it reduces fear and raises one's self-confidence and self-reliance in a peer group. Thus, it is essential that the educators create safe conditions for such exploration and discovery of the local environment by children. In line with this argumentation, children should also be encouraged to critically judge and creatively change their surrounding. In a longer perspective, such an approach is expected to bring stronger identification, deeper concern, and greater involvement with the local community (Breitbart 1995).

Congruency with these theories is apparent in Bridge over the Ocean. The intention behind the project was to use the art of photography in a participatory manner, in order to encourage the young participants to look at their surrounding through the eyes of an artist, that is from a different, unusual angle, so that they could discover and "tame" their relation to the place and its inhabitants, and understand that it could be a relation of a creative kind.

"We wanted the inhabitants themselves to make their photographic autoportrait and show it to others, first in the open air exhibits, and then in the book. It was also about memory: young people photographing their houses, listening to their parents and grandparents, and then exhibiting photos in their own village and in other places - it 
was to be a way to see in a new light the everydayness of one's own place, sometimes perceived as boring or limiting" (Hlebowicz 2008: 8).

It is evident from the pages of the book "Simply Nowa Wola" (comprising children's photos and stories) that the project participants in deed looked at their surrounding from a more artistic perspective: showing sensitivity to details, catching the unobvious, and creating photographs of "an inimitable artistic value" (Froń 2008: 183). This "inimitable artistic value" is not connected to the professional quality of the photographs, though, but to the meaning they have for their authors and the local community.

Analyzing the project from the social art perspective, one should also consider the idea of gift exchange or reciprocity inherent in its framework. It was inspired by the Indian tradition of wampum - a belt of beads that can serve both as a gift, and as a social memory carrier. In the case of the project it was the photographs taken by the young community members (each picture like a colourful bead) that were used as symbolic wampums, in order to initiate dialogue and interaction on multiple levels. Firstly, between the participants themselves; then between the participants and their immediate audiences (the tribe, or the village); and finally, between the two faraway communities of Oneida and Nowa Wola people. To each of these levels a different social function could be ascribed: of creating social bonds through doing something together; of strengthening local identity through sharing images and stories; of changing attitudes towards the Other through getting to better know one. The dissemination methods employed in the project (the exhibitions and book) opened one more possibility of exchange, which would be between a minority and majority group. For it is important to notice that, however geographically and culturally distant, the two local communities involved in the project shared the same experience of a culturally diverse, rural and marginalized group. This is not untypical of social art projects. On the contrary, social art, and participatory photography in particular, is frequently used for the sake of marginalized people's empowerment. Our World in 36 Snapshots provides a more explicit example.

\section{Our World in 36 Snapshots $^{14}$}

The project was carried out in a half-Polish, half-Chechen group of fourteen primaryschool children (8-12 years old) by a group of student volunteers. The children were invited to participate in workshops (to get to better know each other), and to take photographs of their material and social surrounding, and their everyday experiences (to get the others to get to better know them). Their task was simply to photograph "their own world", hence the name of the project. All the children were given free digital cameras and instructed by a professional photographer beforehand, so that they

14 The following description of the project is based on my own research, including observation and five interviews with its animators, whom I cite below. For the project results, see $<$ http://36-klatek.blogspot.com $>$ and Potoniec et al. 2008. 
could all participate in the project and approach the task on equal basis, no matter their social background and prior knowledge of photography. This is not to be underestimated, as according to the contact hypothesis, only when ethnic groups cooperate as equals, the contact between them may result in the expected reduction of prejudice and stereotypes, which was of prime importance to the project initiators.

On the whole, Our World in 36 Snapshots was intended to build up ties between a domineering majority and a stigmatized minority group in the school context. The school selected for the project was one attended by both Polish and Chechen children, but neglecting the problem of contacts and integration between the two groups. The project initiators wanted to encourage intercultural communication, and raise a more cooperative attitude towards each other between the Polish and Chechen schoolchildren. It was also designed to empower the latter, who normally find themselves in a disadvantaged position both as refugees, and as Muslims.

Although the project primarily affected the schoolchildren, the idea behind it was to exert an impact, however indirect and far more difficult to measure, on a wider audience: the whole group of Chechen refugees in Bialystok, the school community, and the other city dwellers. This was achieved through a number of interrelated dissemination tactics, such as: exhibiting the photographs taken by the children in their school, organizing a school fest at the end of the project, printing a booklet with pictures taken by the children, running a website dedicated to the project, and attracting the local media attention.

The effect of the project on the participating children was three-dimensional. Socially, it created supportive conditions for an intergroup contact between the Polish and Chechen children, including mutual recognition, cooperation, and deeper interpersonal relations. Educationally, it provided the children with an opportunity to learn the art of photography in an informal setting. They acquired knowledge and skills, which they could immediately use in practice, and further develop after the project had reached its end. They could keep the cameras they worked with during the project, which was necessary for the Chechen children, as otherwise they would not be able to experiment with photography later on. Psychologically, the newly acquired competences raised the children's self-esteem. It seems that for the Chechen children the mere fact of inviting them to do something together with the Polish children, as well as the time, attention and care showed to them by the project team, made them feel visible, worthy and important:

\footnotetext{
"For those seven children it was a huge event in their lives: that they could take pictures, that somebody wanted to meet and play with them, that they could leave the refugee centre after school, that they could go for a trip, that there was an exhibition of their photographs, that the press wrote about them, that a man from the radio talked to them, that they were on TV..."
}

On the other hand, the integration of the Chechen children turned out to be important for their parents. They were glad to see that their children - through participation in the project - ceased to be labelled as those who do badly at school, and instead were treated as individuals who are capable of completing creative tasks, learning 
and cooperating with other children. They were also proud to see that their children's undertakings got the attention of the local community.

Undoubtedly, the use of participatory photography in the project was of key importance for its integrative and empowering effect on the children. The choice of this method was initially based on the animators' desire to get to know the world of the children as they know it, but it also had a pragmatic justification. Photography, especially digital, is an attractive and interesting activity for children. Although in the case of Our World in 36 Snapshots the children were prepared to work (or actually play) with a photo-camera, in general digital photography does not require any particular competences or talents. At the same time, it is a skill that can be further developed and perfected as a hobby to prolong the impact of the project. Using photography in a group helped to establish and foster mutual relations between its members. During the photographic workshops, the children photographed one another, helped each other to solve technical problems, discussed the pictures that they had individually taken at home or outdoors. The activity of photographing was also used as a pretext to introduce other interesting pastimes, like sightseeing. Within the project framework, the children went together for a trip to get to know the history and cultural diversity of the Podlaski region. It is worth highlighting that in this way their own culture got symbolically connected to other distinct regional cultures as another unique contribution.

\section{Conclusions}

The three projects described above all reflect a wide range of democratic values, such as: grassroots participation; empowerment of the ordinary, the local, and the minor; public expression of one's condition, and articulation of one's needs; reclaiming public spaces for spontaneous social actions and gatherings; bridging differences of cultural and social nature; self-reflection and creativity. None of these could have been achieved under the communist regime.

The communist period had its art, which could not be reduced to socialist realism. It was also the politically disarmed modern formalist vanguard, and the protest art of democratic oppositionists and cultural contesters (dissidents as they were called at the time). The democratic period has its art too, unrestricted to any artistic convention and way of thinking, critical whenever it wants. It also brings a new genre of art, which broadens the idea of citizenship, and resorts to the very basic democratic value - the freedom of expression.

\section{References}

Adams, J. 2002. "Art in Social Movements: Shantytown Women's Protest in Pinochet's Chile", Sociological Forum 17(1): 21-56. doi:10.1023/A:1014589422758

Agosín, M. 2008. Tapestries of Hope, Threads of Love: The Arpillera Movement in Chile. Lanham: Rowan \& Littlefield Publishers Inc.

Baczko, A.; Ogrocka, A. 2008. Wolontariat, filantropia i 1\%. Raport z badań 2007. Warszawa: Stowarzyszenie Klon/Jawor. 
Breitbart, M. M. 1995. "Banners for the Street: Reclaiming Space and Designing Change with Urban Youth", Journal of Planning Education and Research 15: 35-49. doi:10.1177/0739456X9501500103

Froń, A. 2008. "It Is So Wordly-Wise", in Hlebowicz, B. (Ed.). Nowa Wola po prostu: Oczami dzieci. Michałowo, Wielichowo: TIPI, 179-184.

Gliński, P. 1996. Polscy Zieloni: Ruch społeczny w okresie przemian. Warszawa: IFiS PAN.

Golka, M. 1996. Socjologiczny obraz sztuki. Poznań: Ars Nova.

Gumkowska, M. 2009. "Poza Kongresem: Aktywność organizacji pozarządowych w sferze kultury”, Trzeci Sektor 19: 20-27.

Gumkowska, M.; Herbst, J. 2006. Podstawowe fakty o organizacjach pozarzadowych: Raport z badania 2006. Warszawa: Stowarzyszenie Klon/Jawor.

Hlebowicz, B. (Ed.). 2008. Nowa Wola po prostu: Oczami dzieci. Michałowo, Wielichowo: TIPI. Jawłowska, A. 1988. Więcej niż teatr. Warszawa: PIW.

Kucharska, P. 2004. "Kłopotliwy gość. Polska ekspozycja na Międzynarodowej Wystawie Sztuki Krajów Socjalistycznych w Moskwie (1958/1959)". [Last access 26-10-2010]. Available from Internet: $<$ http://www.culture.pl/pl/culture/artykuly/es_katalog2_klopotliwy_gosc >.

Kwon, M. 2002. One Place after Another: Site-Specific Art and Locational Identity. Cambridge, London: The MIT Press.

Marchlewski, W. 1991. „Pomarańczowa Alternatywa: dokumentacja wybranych działań“, in Wertenstein-Żuławski, J.; Pęczak, M. (Eds.). Spontaniczna kultura młodzieżowa: Wybrane zjawiska. Wrocław: Wiedza o Kulturze, 162-187.

Misztal, B. 1992. "Between the State and Solidarity: One Movement, Two Interpretations The Orange Alternative Movement in Poland”, The British Journal of Sociology 43(1): 55-78. doi:10.2307/591201

Niziołek, K. 2008. „Sztuka i aktywność obywatelska”, in Kościański, A.; Misztal, W. (Eds.). Społeczeństwo obywatelskie - teoria i praktyka. Warszawa: IFiS PAN, 235-265.

Niziołek, K. 2009a. „Publiczna, zaangażowana, społecznościowa? O sztuce jako formie aktywności obywatelskiej“, Trzeci Sektor 19: 28-37.

Niziołek, K. 2009b. „Sztuka jako enklawa aktywności obywatelskiej“, in Gołdyka, L.; Machaj, I. (Eds.). Enklawy życia społecznego: Kontynuacje. Szczecin: Wydawnictwo Naukowe US, 205-222.

Nowa sztuka. 1950. Polska Kronika Filmowa. WFDiF (film).

Offe, C. 1995. „Nowe ruchy społeczne: przekraczanie granic polityki instytucjonalnej”, in Szczupaczyński, J. (Ed.). Władza i społeczeństwo: Antologia tekstów z zakresu socjologii polityki. Vol. 1. Warszawa: Scholar.

Ossowska, M. 1992. Wzór demokraty: Cnoty i wartości. Lublin: Daimonion.

Pęczak, M. 1991. „Pomarańczowi - absurd, parodia i polska codzienność“, in Wertenstein-Żuławski, J.; Pęczak, M. (Eds.). Spontaniczna kultura młodzieżowa: Wybrane zjawiska. Wrocław: Wiedza o Kulturze, 188-197.

Piotrowski, P. 2004. „Polska sztuka między totalitaryzmem a demokracją”. [Last access 16-07-2010]. Available from Internet: <http://www.culture.pl/pl/culture/artykuly/es_katalog_ totalitaryzm_demokracja>. 
Potocka, M. A. 2008. To tylko sztuka. Warszawa: Aletheia.

Potoniec, K.; Grzędzińska, A.; Gaworek, A. (Eds.). 2008. Integracja dzieci polskich i czeczeńskich na przykladzie projektu „Nasz świat w 36 klatkach“. Białystok: Fundacja UwB.

Przybylski, R. K. 1993. „Dwadzieścia lat później“, in Golka, M. (Ed.). Sztuka i czas. Poznań: Artia, 19-28.

Smith, O. F. 1998. Fluxus: The History of an Attitude. San Diego: San Diego University Press.

Szreder, K. 2008. „Sztuka publiczności“, Res Publica 4: 42-51.

Wciórka, B. 2008. Polacy o swojej aktywności społecznej: Komunikat z badań. Warszawa: CBOS.

Webster, M. (Ed.). 1997. Community Arts Workers: Finding voices, making choices. Bramcote Hills: Educational Heretics Press.

Zmarz-Koczanowicz, M. 2002. Pokolenie 89/Generation 89. Polskie Wydawnictwo Audiowizualne (a film).

\title{
MENAS IR PILIETINE VISUOMENE: NUO PROTESTO IKI BENDRADARBIAVIMO
}

\author{
Katarzyna Niziołek
}

\begin{abstract}
Santrauka
Straipsnyje, laikydamasi demokratinès transformacijos perspektyvos, autorè susitelkia i̇ meną kaip specifinę pilietinès visuomenès sritị. Analizuojamos ir lyginamos įvairios meninio aktyvumo formos, pasitaikančios Lenkijoje - nuo komunistinio laikotarpio meninio avangardo ir protestinio meno iki šių dienų kultūrinès demokratijos bei socialinio meno praktikos. Daug dèmesio skiriama socialinio meno sampratai, kuri čia aiškinama pateikiant trijų modelių pavyzdžius ir kiekvieną iš jų tiriant skirtinguose kontekstuose - atviroje viešojoje erdvejje, vietinèje bendruomenejje ir mažumos grupejje. Visi šie kontekstai straipsnyje pristatomi kaip skirtingų socialinių funkcijų visumos.

Reikšminiai žodžiai: kultūrinė demokratija, kultūrinès organizacijos, dalyvaujančioji fotografija, protestinis menas, socialinis menas.
\end{abstract}

Received 6 April 2010, accpted 10 June 2010 